\title{
Plant-Parasitic Nematodes Associated with Forage Legumes Planted in Fallow and into Living Grass Sod
}

\author{
Mahfouz M.M. Abd-Elgawad*; Mohamed F.M. Eissa*; Abd-Elmoneim Y. El- \\ Gindi** and Grover C. Smart*** \\ * Phytopathology Department, National Research Centre; \\ ** Department of Agricultural Zoology and Nematology, Faculty of Agriculture, University of Cairo, \\ Giza, Egypt; \\ *** Department of Entomology and Nematology, IFAS, University of Florida, USA.
}

\begin{abstract}
The capability of legumes to fix and provide sufficient nitrogen for crop production has encouraged re-appraisal of cropping systems that utilize relevant forage legumes. However, plant-parasitic nematodes (PPN) can damage forage legumes but differently according to forage legume production systems. Therefore, this study determined the population levels of PPN associated with three different production systems. Different species of forage legumes were planted in fallow soil and into living grass sod of two species; 'Pensacola' bahia grass and 'Tif-81' bermuda grass. Thirteen genera of PPN were associated with one or more cultivars of twelve forage legumes in one or more of three locations in Alachua County near Gainesville, Florida, USA. No significant difference $(P \leq 0.05)$ was found in the nematode population levels among clover cultivars overseeded in dormant bahia grass or bermuda grass sod. However, when clover cultivars were planted in fallow plots, significant differences $(P \leq 0.05)$ occurred in population levels of Meloidogyne spp. Also, significant differences $(P \leq 0.05)$ occurred in populations of Meloidogyne spp. and Criconemella spp. among the three experiments.
\end{abstract}

Key words: bahia grass, bermuda grass, forage legume production systems, plantparasitic nematodes.

\section{Introduction}

Leguminous crops generally represent some of the best quality forages for livestock since they are palatable, help maintain proper functioning of the ruminant digestive processes and stimulate high production of both meat and milk. Also, they are used as green manure by ploughing them into the soil.

Forage legumes have numerous features that can act together at different stages in the soil-plant-animal-atmosphere system, and these are most effective in mixed swards with a legume proportion of 30-50\% (Lüscher et al., 2014). So, they can reduce dependence on fossil energy and industrial $\mathrm{N}$-fertilizer, lower quantities of harmful emissions to the environment (greenhouse gases and nitrate), lower production costs, higher productivity and increased protein self-sufficiency. The 
existence of bioactive secondary metabolites in some legume species can provide scopes for improving animal health with less medication. Also, legumes may offer an adaptation option to rising atmospheric $\mathrm{CO}_{2}$ concentrations and climate change. Legumes offer these merits at both levels of the managed land-area unit and the final product unit (Lüscher et al., 2014).

However, many legumes are very susceptible to damage by plant-parasitic nematodes (PPN), especially the root-knot nematodes, Meloidogyne spp. (Baltensperger et al., 1985a and b), which are endoparasitic forms capable of reproducing not only on forage crops but also on a wide variety of host plants. Nematodes associated with crop losses of temperate and subtropical legumes and methods for their control were reviewed (Hague, 1980). The clover cyst nematode, Heterodera trifolii, was reported to injure white clover (Trifolium repens L.) and red clover (Trifolium pratense L.) in the United States and Europe. Allison (1956) reported sixteen varieties of forage legumes to be susceptible to Meloidogyne javanica, M. incognita, M. incognita acrita, M. arenaria and M. hapla. Baxter and Gibson (1958) noted that poor stands of white clover in South Carolina were often associated with soil infested with root-knot nematodes, Meloidogyne spp. In North Carolina, McGlohon et al. (1961) found the nematode genera Hoplolaimus, the lance nematode; Trichodorus; the stubby root nematode; Tylenchorhynchus, the stunt nematode; Helicotylenchus, the spiral nematode; Pratylenchus, the lesion nematode; Xiphinema, the dagger nematode; Meloidogyne; Heterodera; Criconemella, the ring nematode; and Paratylenchus, the pin nematode associated in various combinations with white clover, red clover and alfalfa (Medicago sativa L.). A report on plant-parasitic nematode distributions illustrated that five plantparasitic species: Meloidogyne arenaria, Pratylenchus minyus, Merlinius brevidens, Helicotylenchus digonicus and Paratrichodorus minor were present consistently in alfalfa at Riverside, California (Goodell and Ferris, 1980). Characteristic root-knot nematode damage (Taylor and Sasser, 1978) was found in a seed-production field of 'Meechee' arrowleaf clover, Trifolium vesiculosum in Stone County, Mississippi (Nichols et al., 1981).

Recently, the potential of biological nitrogen fixation (BNF) to provide sufficient nitrogen for production has encouraged re-appraisal of cropping systems that deploy legumes. It has been argued that legume-derived nitrogen can maintain productivity as an alternative to the application of mineral fertilizer, although few studies have systematically evaluated the effect of optimizing the balance between legumes and non $\mathrm{N}$-fixing crops to optimize production (lannetta et al., 2016). In this vein, forage legume production systems may also affect population levels of PPN differently.

The objective of this study was to determine the population levels of plantparasitic nematode genera associated with three different forage legume production systems. Different species of forage legumes were planted in fallow soil and into 
living grass sod of two species; 'Pensacola' bahia grass (Paspalum notatum) and 'Tif-81' bermuda grass (Cynodon dactylon). 'Pensacola' bahia grass is thought to show moderate resistance to Meloidogyne spp. (McGlohon et al., 1961) while 'Tif81 ' bermuda grass is susceptible.

\section{Materials and Methods}

Soil of three experimental areas with established stands of several adapted clover cultivars were sampled for PPN. The experimental areas, properties of the University of Florida, were located in Alachua County near Gainesville, Florida, USA at a latitude of 30 degrees north and a longitude of 82 degrees west. The three experiments, set up initially to test forage cultivars, had been established in a randomized block design with clover cultivars and controls as treatments (Table 1).

Table (1): List of legume cultivars planted in three different experiments.

\begin{tabular}{|c|c|c|c|}
\hline \multirow[b]{2}{*}{ Cultivar } & \multicolumn{3}{|c|}{ Experiment } \\
\hline & $\begin{array}{c}\text { Bahia grass } \\
\text { sod }^{(\text {a) }}\end{array}$ & $\begin{array}{c}\text { Bermuda } \\
\text { grass sod }^{(\mathbf{b})}\end{array}$ & Fallow $^{(c)}$ \\
\hline \multicolumn{4}{|l|}{ Trifolium repens (L.) } \\
\hline 'FL-XP1' white clover & + & & \\
\hline 'Regal' white clover & + & & \\
\hline 'FL-XP2' white clover & + & & \\
\hline 'LA-SI' white clover & + & & \\
\hline 'Tillman' white clover & \multicolumn{3}{|c|}{+} \\
\hline \multicolumn{4}{|l|}{ T. pratense $(\mathrm{L})}$. \\
\hline 'Kenstar' red clover & + & + & + \\
\hline \multicolumn{4}{|l|}{ T. vesiculosum (Savi) } \\
\hline 'Amclo' arrowleaf clover & + & \multirow{3}{*}{+} & + \\
\hline 'Yuchi' arrowleaf clover & & & + \\
\hline 'REPS-5' arrowleaf clover & & & + \\
\hline \multicolumn{4}{|l|}{ T. incarnatum (L.) } \\
\hline 'Dixie' crimson clover & + & + & + \\
\hline \multicolumn{4}{|l|}{ T. subterraneum (L.) } \\
\hline 'Mt. Barker' subterranean clover & + & & + \\
\hline 'Woogenellup' subterranean clover & & + & + \\
\hline \multicolumn{4}{|l|}{ T. alexandrinum (L.) } \\
\hline 'Bigbee' Egyptian clover & & & + \\
\hline \multicolumn{4}{|l|}{ Medicago sativa } \\
\hline 'FL-77' alfalfa & & + & + \\
\hline \multicolumn{4}{|l|}{ Melilotus alba var_annua } \\
\hline 'Hubam' sweet člover (DESV.) & & + & \\
\hline \multicolumn{4}{|l|}{ Paspalum notatum (Flüggé) } \\
\hline 'Pensacola' bahia grass (control) & + & & \\
\hline \multicolumn{4}{|l|}{ Cynodon dactylon (L.) Pers } \\
\hline 'Tif-81' bermuda grass (control) & & + & \\
\hline Fallow (control) & & + & \\
\hline
\end{tabular}

(a) The plots were planted to bahia grass in May,1971; the dormant grass overseeded with the legume cultivars in October 1981, and soil samples taken and nematodes extracted in May, 1983.

(b) The plots were planted to bermuda grass in June, 1979; the dormant grass overseeded with the legume cultivars in October, 1981, and soil samples taken and nematodes extracted in June, 1983.

(c) The plots were established in a clean seed bed in October, 1982, soil samples taken and nematodes extracted in May, 1983. 
1. Bahia grass sod: Bahia grass was established at the Beef Research Unit north of Gainesville in May 1971 in plots measured $1.8 \times 4.9 \mathrm{~m}$. In October 1981, the clover cultivars were overseeded into the dormant bahia grass (Table 2). The bahia grass grew along with clovers in season but became dormant each winter. The control plots were bahia grass without overseeding clover. Each treatment was replicated four times. The soil type is Wauchula sand (Sandy, siliceous, hyperthermic Ultic Hoplaquads). In May 1983, 19 months after the legumes were overseeded into the bahia grass sod, soil samples were taken with an Esser cone sampler (Esser et al., 1965). About five 2.5-cm diameter cores were taken randomly within the root zone (upper $15-20 \mathrm{~cm}$ ) from each plot and then mixed thoroughly to form one sample representing the plot. Each sample was placed in a plastic bag, stored in an ice chest, and transported to the nematology laboratory. Samples not processed immediately were stored at $10 \pm 1^{\circ} \mathrm{C}$ until processed. Nematodes were extracted from $100 \mathrm{~cm}^{3}$ soil from each sample using a centrifugal-flotation technique (Caveness and Jensen, 1955), placed in vials, and stored in a refrigerator at $4^{\circ} \mathrm{C}$ for no more than three days until identified to genera and counted.

Table (2): Genera and mean numbers of plant-parasitic nematodes on clover cultivars two years after planting into living bahia grass sod*.

\begin{tabular}{|c|c|c|c|c|c|c|c|c|}
\hline Cultivar & 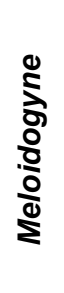 & 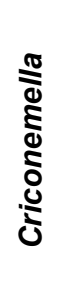 & 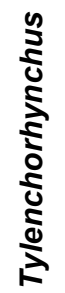 & 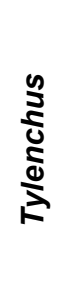 & 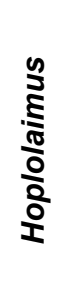 & 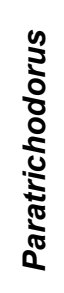 & 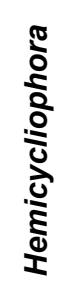 & 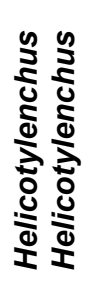 \\
\hline 'FL-XP1' white clover & 0 & 26 & 22 & 5 & 0 & 0 & 459 & 45 \\
\hline 'Regal' white clover & 0 & 26 & 0 & 34 & 0 & 0 & 246 & 85 \\
\hline 'FL-XP2' white clover & 0 & 29 & 0 & 11 & 6 & 0 & 580 & 55 \\
\hline 'LA-SI' white clover & 0 & 22 & 0 & 5 & 0 & 0 & 600 & 127 \\
\hline 'Amclo' arrowleaf clover & 0 & 16 & 11 & 0 & 0 & 0 & 296 & 66 \\
\hline 'Mt. Barker' subterranean clover & 0 & 47 & 10 & 15 & 0 & 0 & 371 & 43 \\
\hline 'Kenstar' red clover & 0 & 16 & 0 & 0 & 0 & 0 & 460 & 37 \\
\hline 'Dixie' crimson clover & 9 & 10 & 0 & 0 & 0 & 10 & 338 & 103 \\
\hline 'Pensacola' bahia grass (control) & 0 & 25 & 15 & 15 & 0 & 0 & 292 & 45 \\
\hline Statistical significance $(P \leq 0.05)$ & NS & NS & NS & NS & NS & NS & NS & NS \\
\hline
\end{tabular}

* Nematode genera per $100 \mathrm{~cm}^{3}$ soil. Bahia grass (Paspalum notatum) sod had been growing in the plots for 12 years prior to sampling and for 10 years and 5 months before the legumes were seeded. Bahia grass was established at the Beef Research Unit, University of Florida, Gainesville, Florida, USA. The soil type is Wauchula sand. NS = not significant. 
2. Bermuda grass sod: Bermuda grass was established on the main Agronomy Farm in June 1979 in plots measured $3.7 \times 6.1 \mathrm{~m}$. In October 1981, the clover cultivars were overseeded into the dormant bermuda grass. The berrnuda grass grew along with clovers in season but became dormant each winter. The control plots were bermuda grass without overseeding clover. Each treatment was replicated six times. The soil type is Arredondo fine sand (loamy, siliceous, hyperthermic Grossarenic paleudults). In June 1983, 20 months after the legumes were overseeded into the bermuda grass sod (Table 3), soil samples were taken and processed as for the previous experiment.

Table (3): Genera and mean numbers of plant-parasitic nematodes on clover cultivars two years after planting into living bermuda grass sod*.

\begin{tabular}{|c|c|c|c|c|c|c|c|c|c|}
\hline Cultivar & 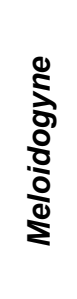 & 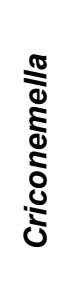 & 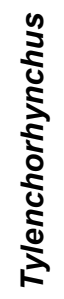 & $\begin{array}{l}\text { S } \\
\frac{d}{d} \\
\frac{d}{d}\end{array}$ & $\begin{array}{l}\mathfrak{n} \\
\stackrel{n}{\frac{\pi}{2}} \\
\frac{0}{0} \\
\frac{2}{2}\end{array}$ & $\begin{array}{l}3 \\
\frac{0}{0} \\
0 \\
\frac{0}{0} \\
\frac{0}{0} \\
\frac{0}{\pi}\end{array}$ & 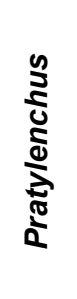 & 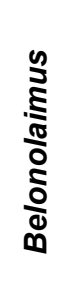 & $\begin{array}{l}\frac{y}{D} \\
\frac{\delta}{d} \\
\frac{\delta}{d} \\
\frac{d}{d} \\
\frac{\alpha}{d}\end{array}$ \\
\hline 'Kenstar' red clover & 211 & 204 & 0 & 0 & 0 & 0 & 180 & 50 & 0 \\
\hline 'Tillman' white clover & 71 & 45 & 27 & 7 & 0 & 0 & 54 & 22 & 0 \\
\hline 'Dixie' crimson clover & 140 & 77 & 18 & 6 & 0 & 31 & 33 & 10 & 6 \\
\hline 'Woogenellup' subterranean clover & 135 & 57 & 0 & 0 & 0 & 6 & 13 & 6 & 0 \\
\hline 'Yuchi' arrowleaf clover & 93 & 183 & 0 & 9 & 0 & 0 & 31 & 0 & 0 \\
\hline 'Hubam' sweet clover & 135 & 49 & 5 & 0 & 12 & 0 & 31 & 6 & 0 \\
\hline 'FL-77' alfalfa & 110 & 30 & 4 & 4 & 4 & 4 & 37 & 9 & 9 \\
\hline 'Tif-81' bermuda grass (control) & 82 & 77 & 0 & 0 & 0 & 11 & 15 & 17 & 0 \\
\hline Statistical significance $(P \leq 0.05)$ & NS & NS & NS & NS & NS & NS & NS & NS & NS \\
\hline
\end{tabular}

* Nematode genera per $100 \mathrm{~cm}^{3}$ soil. Bermuda grass (Cynodon dactylon) sod had been growing in the plots for four years prior to sampling and for two years and four months before the legumes were seeded. Location was the Agronomy Farm, University of Florida, Gainesville, Florida, USA. The soil type is Arredondo fine sand. NS = not significant.

3. Fallow: This experiment also was established at the main Agronomy Farm. Each plot measured $2.1 \times 6.1 \mathrm{~m}$ with each clover cultivar and the fallow control replicated five times (Table 4). The soil type is Lake sand (Hyperthermic, coated Typic Quartzipsamments). Plots were planted to lupine, Lupinus termis, and bean, Vicia faba for eight months and then left fallow for four months before the experiment was established. Samples were taken and processed as for the first experiment. 
Table (4): Genera and mean numbers of plant-parasitic nematodes on clover cultivars eight months after planting in fallow ground*.

\begin{tabular}{|c|c|c|c|c|c|c|c|c|}
\hline Cultivar & $\begin{array}{l}\stackrel{0}{\vdots} \\
\text { ○े } \\
\stackrel{0}{0} \\
\stackrel{0}{0}\end{array}$ & 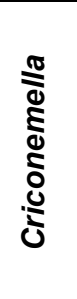 & 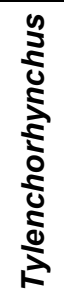 & 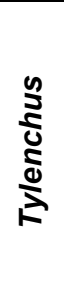 & 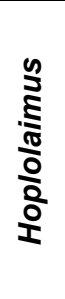 & 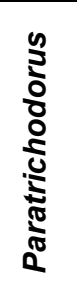 & 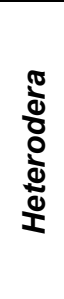 & 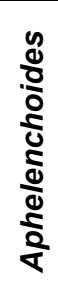 \\
\hline 'Amclo' arrowleaf clover & $3374 a b$ & 130 & 0 & 0 & 5 & 0 & 0 & 0 \\
\hline 'Yuchi' arrowleaf clover & $1464 \mathrm{bc}$ & 126 & 0 & 0 & 6 & 0 & 0 & 26 \\
\hline 'REPS-5' arrowleaf clover & $953 \mathrm{bc}$ & 40 & 16 & 3 & 0 & 48 & 0 & 0 \\
\hline 'Dixie' crimson clover & $986 \mathrm{bc}$ & 62 & 0 & 0 & 0 & 0 & 0 & 0 \\
\hline 'Bigbee' Egyptian clover & $4301 a$ & 16 & 0 & 36 & 7 & 0 & 0 & 0 \\
\hline 'Mt. Barker' subterranean clover & $1600 \mathrm{bc}$ & 77 & 0 & 8 & 5 & 0 & 0 & 0 \\
\hline 'Woogenellup' subterranean clover & $2247 b$ & 126 & 0 & 4 & 0 & 0 & 0 & 0 \\
\hline 'FL-77' alfalfa & $182 \mathrm{c}$ & 55 & 14 & 12 & 0 & 35 & 0 & 0 \\
\hline 'Kenstar' red clover & $533 c$ & 59 & 0 & 0 & 0 & 315 & 8 & 8 \\
\hline Fallow (control) & $150 c$ & 207 & 4 & 0 & 0 & 0 & 0 & 0 \\
\hline Statistical significance $(P \leq 0.05)$ & - & NS & NS & NS & NS & NS & NS & NS \\
\hline
\end{tabular}

* Nematode genera per $100 \mathrm{~cm}^{3}$ soil. The previous crops lupine (Lupinus termis) and broad bean (Vicia faba) grew for eight months and the plots were left fallow for four months prior to planting the tested cultivars. Location was the Agronomy Farm, University of Florida, Gainesville, Florida, USA. The soil type is Lake sand. NS = not significant. In a column, figures followed by the same letter are not statistically significant $(P \leq 0.05)$.

Statistical analysis. Data were subjected to analysis of variance and averages of population levels for each nematode genus as well as its levels among the three experimental sites were compared using Duncan's New Multiple Range Test.

\section{Results}

1. Bahia grass sod: At the Beef Research Unit, three to six genera of plant-parasitic nematodes were associated with each of the tested clover cultivars (Table 2). Criconemella spp., Hemicycliophora spp. and Helicotylenchus spp. were present on all cultivars, while Meloidogyne spp., Hoplolaimus spp. and Paratrichodorus spp., each were present only on one clover cultivar. There were no significant difference $(P \leq 0.05)$ in nematode population density among cultivars.

2. Bermuda grass sod: Each of the clover cultivars at this site of the Agronomy 
Farm had from four to nine plant-parasitic nematode genera associated with it (Table 3). Meloidogyne spp., Criconemella spp. and Pratylenchus spp. were present on each tested cultivar while Tylenchorhynchus spp., Tylenchus spp., Hoplolaimus spp., Paratrichodorus spp., Belonolaimus spp. and Aphelenchus spp., each were present on at least two clover cultivars. Population density levels of Criconemella spp. and Meloidogyne spp., were the highest. There were no significant differences $(P \leq 0.05)$ in nematode population densities among tested cultivars.

3. Fallow: Each of the tested clover cultivars at this location had from two to five genera of plant-parasitic nematodes associated with it (Table 4). Meloidogyne spp. and Criconemella spp. were present on all tested clover cultivars while Tylenchorhynchus spp., Tylenchus spp., Hoplolaimus spp., Paratrichodorus spp., Heterodera spp. and Aphelenchoides spp., each were present on at least one clover cultivar. There were significant differences $(P \leq 0.05)$ only in Meloidogyne spp. population density among cultivars. Population density levels of Meloidogyne spp. were higher than those of any other plant parasitic nematode genus. Criconemella spp. in the bermuda grass sod and fallow experiments were significantly $(P \leq 0.05)$ higher than in the bahia grass sod experiment. Meloidogyne larvae in the fallow experiment were significantly $(P \leq 0.05)$ higher than in either of the other two experiments.

\section{Discussion}

The nematode genera Criconemella spp., Hemicycliophora spp. and Helicotylenchus spp. were present consistently in the soil samples of clovers planted into living 'Pensacola' bahia grass sod at the Beef Research Unit. It appears that clover cultivars and/or bahia grass are good hosts for the aforementioned nematode genera. Apparently, the genus Hemicycliophora spp. is favored by this soil, i.e. sandy, poorly drained, siliceous soil since its population levels were highest of all genera. This agrees with the report of Chitwood (1957) who collected Hemicycliophora floridensis from a swampy road. Recently, Lopez et al. (2013) could morphologically differentiate Hemicycliophora labiata from $\mathrm{H}$. floridens. The other five nematode genera were too low in their population levels to be considered statistically in this comparison. The location was almost free of Meloidogyne spp. possibly because it was frequently flooded which agrees with Brown (1933) who reported flooding to control Meloidogyne spp. It is possible that bahia grass, which was present for 10 years before the legumes were seeded in dormant sod, and which continued to grow in season was responsible for the non-significant differences $(P \leq 0.05)$ among population levels for each nematode genus. If so, bahia grass had more controlling influence over nematode populations than did legume cultivars. This agrees with McGlohon et al. (1961) report that 'Pensacola' bahia grass showed resistance to Meloidogyne spp. 
All legume cultivars planted into living 'Tif-81' bermuda grass sod were hosts for the nematode genera Meloidogyne spp., Criconemella spp. and Pratylenchus spp. It is possible that bermuda grass, which was present for about two years before the legumes were seeded in dormant sod, and which continued to grow in season was responsible for the non-significant differences $(P \leq 0.05)$ among population levels for each nematode genus. If so, bermuda grass had more controlling influence over nematode populations than did legume cultivars. This appears to be consistent with Good et al. (1964) report that 'Coastal' bermuda grass was a nematode-reducing plant.

Population levels of Meloidogyne spp. varied significantly $(P \leq 0.05)$ among legume cultivars planted in the fallow. Lowest population levels of Meloidogyne spp. $(P \leq 0.05)$ were on 'Kenstar' red clover, 'FL-77' alfalfa, and in the fallow control.

Low populations on 'FL-77' alfalfa agrees with the report of Baltensperger et al. (1985a) who found some resistance in 'FL-77' alfalfa to Meloidogyne spp. Highest population levels of Meloidogyne spp. were on 'Bigbee' Egyptian clover and 'Amclo' arrowleaf clover. Yousif (1979), Taha et al. (1974) and Baltensperger et al. (1985a) reported similar results on Egyptian clover and Baltensperger et al. (1985b) reported similar results on arrowleaf clover in the greenhouse tests. Intermediate population levels of nematodes were found on 'Yuchi' arrowleaf clover, 'RRPS-5' arrowleaf clover, 'Dixie' crimson clover, 'Mt. Barker' subterranean clover and 'Woogenellup' subterranean clover with non-significant differences $(P \leq 0.05)$ among them. McGlohon and Baxter (1958) tested twenty-five species of clovers, Trifolium spp., for resistance to $M$. incognita acrita and found that all were susceptible with 15 to 18 plants of each species severely galled.

Comparing nematode populations on clover cultivars in different locations is difficult because of differences in soil type, drainage and the established grass sod. However, since significant differences $(P \leq 0.05)$ occurred in Meloidogyne spp. populations in the fallow experiment, it seems likely that bahia grass and bermuda grass were responsible for the non-significant differences among nematode populations which occurred in those two experiments. Data on nematode populations on the legume cultivars supported the phenomenon of uneven distribution of nematodes in the field as reported by Abd-Elgawad and Hasabo (1995) in berseem clover fields of Egypt.

Lüscher et al. (2014) stressed that the development of legume-based grassland-livestock systems undoubtedly constitutes one of the pillars for more sustainable and competitive ruminant production systems. Also, biological nitrogen fixation through grain and forage legumes has the potential to generate major benefit in terms of reducing or dispensing with the need for mineral nitrogen without loss of total output (lannetta et al., 2016). However, PPN in established forage legumes of the present study indicated that these legumes are likely suffering from 
some limitations related to the PPN (Baltensperger et al., 1985a and b). Future research to manage these PPN and exploit more fully the opportunities that legumes can offer is desperately needed so that forage legumes will become more important in the future.

\section{Acknowledgement}

This study was supported in part by the NRC In-house project entitled 'Pesticide alternatives against soilborne pathogens attacking legume cultivation in Egypt'.

\section{References}

Abd-Elgawad, M.M. and Hasabo, S.A. (1995). Spatial distribution of the phytonematode community in Egyptian berseem clover fields. Fundamental and Applied Nematology 18(4), 329-334.

Allison, J.L. (1956). Root knot of perennial forage legumes. Phytopathology 46: 6.

Baltensperger, D.D., Quesenberry, K.H., Homer, E.S., Dunn, R.A. and AbdElgawad, M.M. (1985a). Interaction of alfalfa recurrent phenotypic selection cycles with root-knot nematodes. Soil and Crop Science Society of Florida Proceedings. 44, 162-164.

Baltensperger, D. D., Quesenberry, K. H., Dunn, R. A. and Abd-Elgawad, M. M. (1985b). Root-knot nematode interaction with berseem clover and other temperate forage legumes. Crop Science 25, 848-851.

Baxter, L.W. and Gibson, P.B. (1958). Root-knot nematodes cause injury to white clover. South Carolina Agric. Exper. Sta. Ann. Rep. 70: 29-30.

Brown, L.N. (1933). Flooding to control root-knot nematodes. Journal of Agricultural Research 47: 883-888.

Caveness, F.E and Jensen, H.J. (1955). Modification of the centrifugal-flotation technique for the isolation and concentration of nematodes and their eggs in soil. Proceedings of the Helminthological Society of Washington 22: 8789.

Chitwood, B. G. (1957). Who collected Hemicycliophora floridensis new species. Proceedings of the Helminthological Society of Washington 24: 83-84.

Esser, R.P., MacGowan, J.B. and Van Pelt, H.M. (1965). Two new nematode subsampling tools. Plant Disease Reporter 49: 265-267.

Good, M.M, Minton, N.A. and Jaworski, C.A. (1964). Relative susceptibility of selected cover crops and coastal bermuda grass to plant nematodes. Phytopathology 55: 1026-1030. 
Goodell, P.B. and Ferris, H. (1980). Plant parasitic nematode distributions in an alfalfa field. Journal of Nematology 12: 136-141.

Hague, N.G.M. (1980). nematodes of legume crops. In Advances in legume science. Vol. 1, Proceedings of International Legume Conference, Dept. Zoology, Univ. Reading, Reading, UK, pp. 199-205.

lannetta, P.P.M., Young, M., Bachinger, J., Bergkvist, G., Doltra, J., LopezBellido, R.J., Monti, M., Pappa, V.A., Reckling, M., Topp, C.F.E., Walker, R.L., Rees, R.M., Watson, C.A., James, E.K., Squire, G.R. and Begg, G.S. (2016). A comparative nitrogen balance and productivity analysis of legume and non-legume supported cropping systems: the potential role of biological nitrogen fixation. Frontiers in Plant Science 7:1700. doi: 10.3389/fpls.2016.01700

Lopez, M.AC., Robbins, R., and Szalanski, A.L. (2013). Taxonomic and molecular identification of Hemicaloosia, Hemicycliophora, Gracilacus and Paratylenchus species (Nematoda: Criconematidae). Journal of Nematology 45:145-171.

Lüscher, A., Mueller-Harvey, I., Soussana, J.F., Rees, R.M. and Peyraud, J.L. (2014). Potential of legume-based grassland-livestock systems in Europe: a review. Grass and Forage Science 69: 206-228.

McGlohon, N.E. and Baxter, L.W. (1958). the reaction of Trifolium species to the Southern root-knot nematode Meloidogyne incognita var acrita. Plant Disease Reporter 42: 1167-1168.

McGlohon, N.E., Sasser, J.S. and Sherwood, R.T. (1961). Investigations on plantparasitic nematodes associated with forage crops in North Carolina. Technical Bulletin 148, North Carolina Agricultural Experiment Station, Raleigh, NC, USA, 39 pp.

Nichols, R.L., Minton, N.A., Knight, W.E., and Moore, W.F. (1981). Meloidogyne incognita en trebol "arrowleaf". Nematropica 11: 191-192.

Taha, A.H.Y., Yousif, G.M. and El-Hadidy, T.T. (1974). Interaction of root-knot nematode infection and symbiotic nitrogen fixation in leguminous hosts. Annals of Agricultural Sciences, Faculty of Agriculture, Ain Shams University 19(1): 33-38.

Taylor, A.L. and Sasser, J.N. (1978). Bilogy, identification and control of root-knot nematodes (Meloidogyne spp.) Raleigh, North Carolina State Univ. Graphics, NC, USA.

Yousif, G.M. (1979). Histological responses of four leguminous crops infected with Meloidogyne incognita. Journal of Nematology 11: 395-401. 


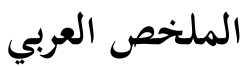

النيماتودا المتطفلة نباتيا المرتبطة بالبقوليات العلفية المنزرعة منفردة أو مع أعشاب نامية

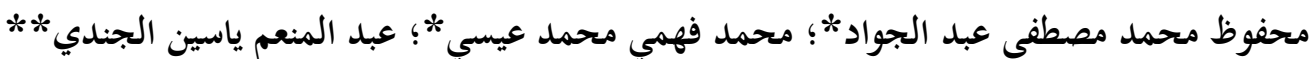

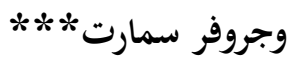

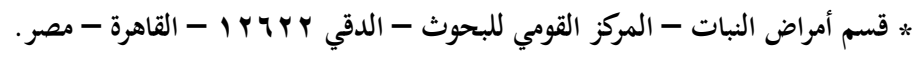

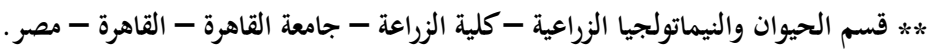

***: قسم الحشرات والنيماتولجي - معهد علوم الغذاء والزراعة - جامعة فلوريدا - الولايات المتحدة الأمريكية.

لقد شجعت قدرة البقوليات على تثبيت وتوفير النيتروجين الجوي بما يكفي لإنتاج المحاصيل

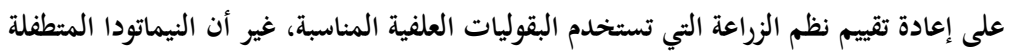

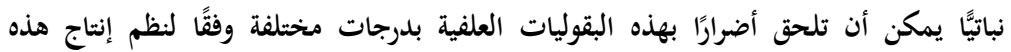
البقوليات. لذلك حددت هذه الدراسة مستويات أجناس هذه النيماتودا المرتبطة بثلاثة أنظمة النيات زراعية مختلفة لإنتاج هذه البقوليات تشمل زراعة أنواع مختلفة من البقوليات العلفية منفردة أو مدات مدات

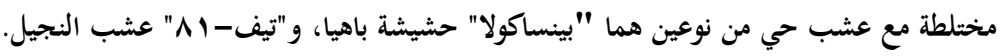

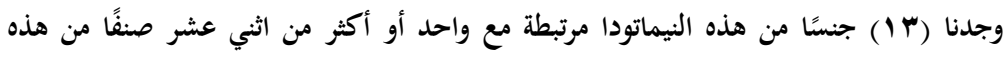

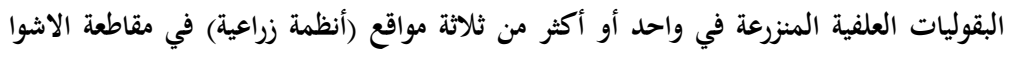

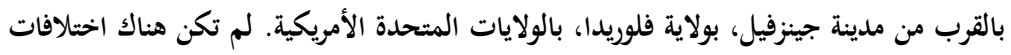

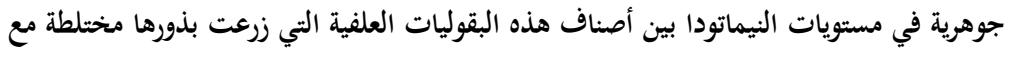

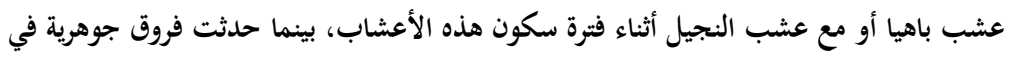

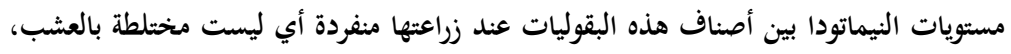

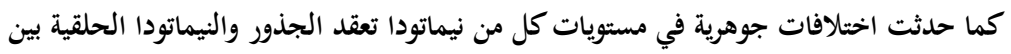

$$
\text { التجارب الثلاث. }
$$

الكلمات الدالة: عشب باهيا، عشب النجيل، نظم إنتاج بقوليات علفية، النيماتودا المتطفلة نباتيَّا. 